\title{
Pengetahuan Matematis Siswa dalam Materi Bentuk Pangkat dan Akar
}

\author{
Andika $^{1}$, Mariyam $^{2}$, Nurul Husna ${ }^{3}$ \\ STKIP Singkawang, Singkawang, Indonesia \\ andikanine@gmail.com ${ }^{1, *)}$, mariyam.180488@gmail.com ${ }^{2}$, nuna_husna@ymail.com \\ ${ }^{*}$ Corresponding author
}

\section{Kata kunci :}

Pengetahuan Matematis;

Bentuk Pangkat; Bentuk Akar

\begin{abstract}
ABSTRAK
Tujuan penelitian ini adalah untuk mendeskripsikan persentase kemampuan, bentuk kesulitan, dan faktor penyebab pengetahuan matematis siswa. Jenis penelitian yang digunakan adalah penelitian deskriptif kualitatif. Subjek dalam penelitian ini adalah siswa kelas X SMA Negeri 4 Singkawang dengan jumlah 30 siswa. Pengambilan data menggunakan instrumen berupa tes uraian yang disesuaikan dengan kemampuan kompetensi strategis matematis dan telah diuji menggunakan validasi isi, validasi konstruk, reliabilitas, daya pembeda, dan tingkat kesukaran. Teknik analisis data yang digunakan adalah penskoran, pedeskripsian data, dan wawancara. Hasil Penelitian menunjukan bahwa (1) Persentase kemampuan pengetahuan matematis dari 30 siswa yaitu 39\% siswa memiliki tingkat pengetahuan yang tinggi, $11 \%$ siswa memiliki tingkat pengetahuan sedang, dan $50 \%$ siswa memiliki tingkat pengetahuan rendah. (2) Bentuk kesulitan siswa dalam menyelesaikan yaitu fakta (kesulitan dalam mengenal dan menuliskan fakta), konsep (kesulitan dalam mengenal dan menuliskan konsep), prinsip (kesulitan dalam mengenal dan menuliskan prinsip), dan notasi (kesulitan dalam mengenal dan menuliskan notasi). (3) Faktor yang mempengaruhi kemampuan pengetahuan matematis siswa berasal dari faktor internal yaitu siswa kebingungan atau lupa cara mengerjakannya, tidak adanya motivasi, minat dan tidak memahami soal dengan baik.
\end{abstract}

\section{PENDAHULUAN}

Matematika merupakan mata pelajaran pokok yang dipelajari pada tingkat dasar, menengah, atas bahkan perguruan tinggi. Lima alasan perlu belajar matematika karena matematika merupakan (1) sarana berpikir yang jelas dan logis, (2) sarana untuk memecahkan masalah dalam kehidupan seharihari, (3) sarana mengenal pola-pola hubungan dan generalisasi pengalaman, (4) sarana untuk mengembangakan kreativitas dan (5) sarana untuk meningkatkan kesadaran terhadap perkembangan budaya (Wahyuni, 2016: 81). Menurut Wahyuni, Mariyam, dan Sartika (2018: 26), matematika merupakan ilmu dasar dalam perkembangan ilmu pengetahuan dan teknologi yang semakin berkembang pesat. Oleh karena itu, matematika merupakan salah satu mata pelajaran dalam pendidikan formal yang wajib dipelajari di setiap jenjang pendidikan di Indonesia Oleh karena itu, 
matematika merupakan salah satu mata pelajaran dalam pendidikan formal yang wajib dipelajari di setiap jenjang pendidikan di Indonesia. Tujuan mata pelajaran matematika untuk jenjang pendidikan sekolah menengah atas yang dituliskan oleh Permendikbud nomor 23 tahun 2016 pasal 3 nomor 1 tentang standar penilaian untuk satuan pendidikan dasar dan menengah adalah setiap lulusan satuan pendidikan dasar dan menengah memiliki kompetensi pada tiga dimensi yaitu sikap, pengetahuan, dan keterampilan. Dalam pembelajaran matematika di sekolah yang menerapkan kurikulum 2013, pada aspek pengetahuan lebih menekankan pada hasil belajar kognitif. Hasil belajar kognitif berorientasi pada kemampuan berpikir yang mencakup kemampuan intelektual siswa yang lebih luas dan mendasar. Menurut Zarkasyi (2015: 80), pada pembelajaran matematika terdapat aspek-aspek kognitif yang mencakup perilaku-perilaku yang menekankan aspek intelektual seperti kemampuan matematis (mathematical abilities), yaitu keterampilan dasar yang diperlukan untuk dapat melakukan manipulasi matematika dan kemampuan berpikir dalam matematika.

Perkembangan kognitif dalam pembelajaran matematika menjadi sangat penting bagi siswa yang akan dihadapkan kepada persoalan-persoalan yang menuntut kemampuan berpikir siswa. Perkembangan kognitif sering menjadi pertimbangan mendasar dalam pembelajaran matematika, khususnya yang menyangkut isi atau tujuan pembelajaran yang akan dipelajari. Kognitif dalam pembelajaran matematika mempunyai beberapa aspek yang harus dikuasai, salah satunya adalah aspek pengetahuan matematis. Pengetahuan matematis juga menjadi sebuah tolak ukur yang mendasar untuk pemikiran siswa yang berlanjut ke tahap pemikiran yang lebih sulit. Sebagaimana disebutkan Taksonomi Bloom, kawasan kognitif terdiri atas enam tingkatan, yaitu (1) pengetahuan (knowledge), (2) pemahaman (comprehension), (3) penerapan (application), (4) analisis (analysis), (5) sintesis (synthesis), dan (6) evaluasi (evaluation) (Amelia, 2014: 2). Berdasarkan aspek kognitif tersebut menunjukan bahwa pengetahuan matematis merupakan aspek tingkatan dasar yang merupakan aspek yang mengukur kemampuan siswa untuk ke tahapan yang lebih tinggi.

Pengetahuan matematis adalah kemampuan mengenal dan mengetahui fakta, konsep, sifat, aturan, atau simbol dalam matematika (Zarkasyi, 2015: 81). Pengetahuan matematis bagi siswa dalam proses berpikir sangat diperlukan, karena siswa berpikir secara sistematis untuk menyelesaikan masalah yang ada. Seperti mengingat materi sebelumnya akan berlanjut ke pemahaman kemudian pemahaman akan berlanjut ke penerapan sampai ke evaluasi. Pengetahuan matematis yang mencakup mengingat dan mengenal konsep, fakta dan sifat-sifat merupakan ide abstrak yang dapat digunakan untuk menyatakan sekumpulan objek, apakah objek tertentu merupakan konsep, fakta ataukah sifat-sifat.

Berdasarkan uraian tersebut dapat disimpulkan bahwa pengetahuan matematis merupakan pengetahuan yang sangat penting dan diperlukan dalam pembelajaran matematika. Pengetahuan matematis menjadi tolak ukur kemampuan dasar yang dimiliki siswa, karena dalam mengenal dan mengingat hal yang mendasar merupakan tingkatan yang melangkah ketahapan yang lebih sulit. Seperti mengenal dan mengingat fakta, konsep, sifat-sifat, simbol-simbol, notasi dan aturan matematika yang nantinya akan berlanjut ke pemahaman sampai ke evaluasi. Perkembangan pengetahuan matematis pada dasarnya terbentuk dari aktifitas siswa dalam proses pembelajaran, di mana siswa lebih aktif dalam proses pembelajaran. Menurut Haji (2015: 218), pengetahuan dibangun melalui proses pembelajaran yang aktif. Siswa aktif dalam mengamati objek, melakukan manipulasi objek, dan menemukan fakta, konsep, prinsip, maupun algoritma. Sehingga ingatan siswa akan lebih tajam dari proses tersebut. Namun, kenyataannya di SMA Negeri 4 Singkawang, masih banyak siswa kesulitan ketika menyelesaikan permasalahan matematika dan sering lupa dengan apa yang sudah diajarkan oleh guru. Hal ini disebabkan siswa kurang aktif dalam pembelajaran yang akhirnya lupa dengan materi-materi yang sudah diajarkan. faktor yang dialami oleh siswa ini dapat dipengaruhi oleh berbagai aspek, salah satunya aspek intelektual.

Kesulitan dalam proses pembelajaran matematika juga bisa terjadi dikarenakan lemahnya aspek-aspek pengetahuan matematisnya. Hal ini bisa diketahui dari beberapa hasil penelitian yang dilakukan Sulistyarini (2016) yang menyatakan bahwa siswa kelas X SMK Citra Medika Sukoharjo dalam menyelesaikan soal bilangan bentuk akar dan alternatif pemecahan masalahnya. Dari hasil analisis 
data diketahui kesulitan siswa dalam menyelesaikan soal bilangan bentuk akar adalah karena kesalahan konseptual, prosedur dan faktor penyebab kesulitan siswa tersebut antara lain kurang kuatnya konsep bentuk akar yang dimiliki siswa sehingga terjadi miskonsepsi pada siswa. Sejalan dengan penelitian Azis (2015), analisis kesulitan kognitif siswa SMA dalam belajar matematika diperoleh hal-hal sebagai berikut: (1) Tingkat kesulitan belajar matematika yang dialami oleh siswa untuk menyelesaikan soal-soal Ujian Nasional berada pada kategori sedang. (2) Letak kesulitan belajar matematika siswa pada aspek kognitif dalam menyelesaikan soal-soal dilihat dari segi pengetahuan yaitu (a) faktual, (b) konseptual, dan (c) prosedural.

Lebih lanjut berdasarkan hasil observasi diketahui bahwa pada saat pembelajaran untuk kepentingan evaluasi, kebanyakan guru menggunakan soal-soal yang sifatnya prosedural dan soal pemecahan masalah, padahal di sisi lain kemampuan dasar siswa yaitu pengetahuan matematis belum sepenuhnya dikuasai. Hal ini terjadi pada siswa kelas X SMA Negeri 4 Singkawang yang dibuktikan dengan hasil wawancara peneliti dengan guru bidang studi matematika yang bersangkutan tentang pengetahuan siswa dalam mereview materi bentuk pangkat dan akar yang dipelajari sebelumnya. Berdasarkan hasil wawancara diketahui siswa masih kurang mengingat dikarenakan lupa yang disebabkan tidak mencatat apalagi saat ditanya tentang sifat-sifat bentuk pangkat dan akar siswa tidak bisa menjawab dan ada yang belum paham dengan konsep. Jawaban yang diberikan guru bidang studi tersebut bisa diidentifikasi bahwa siswa masih ada yang lemah pengetahuan matematisnya, hal tersebut bisa dilihat saat siswa diminta untuk menyebutkan sifat-sifat dari bilangan berpangkat, siswa hanya diam dikarenakan lupa dan tidak paham dengan konsep materi yang sudah diajarkan sebelumnya.

Berdasarkan dari uraian sebelumnya, penulis merasa perlu untuk mengidentifikasi kemampuan pengetahuan siswa dalam menyelesaikan kemampuan mengenal dan mengetahui fakta, konsep, sifat, aturan atau simbol dalam matematika, Sehingga penulis tertarik untuk melakukan penelitian yang berjudul "Pengetahuan Matematis Siswa dalam Materi Bentuk Pangkat dan Akar". Penelitian ini diharapkan dapat dijadikan sebagai evaluasi agar siswa memiliki pengetahuan matematis yang baik dalam proses pembelajaran.

Agar di dalam penelitian ini tidak terjadi penafsiran yang berbeda terhadap istilah yang digunakan, untuk itu perlu dijelaskan istilah-istilah atau definisi yang digunakan dalam penelitian ini. Pengetahuan matematis siswa yang dimaksud dalam penelitian ini adalah aspek kognitif yang mengukur kemampuan siswa dalam mengenal dan mengingat suatu konsep, prinsip, fakta atau istilah, rumus dan definisi dalam pelajaran matematika. Adapun indikator kemampuan pengetahuan matematis adalah sebagai berikut: (a) Mengenal fakta, konsep, sifat, atau aturan matematika. (b) Mengenal simbol, notasi, dan bentuk representasi matematis, seperti tabel, diagram, grafik, dan lainlain. (c) Mendefinisikan konsep secara verbal atau tulisan. (d) Menuliskan fakta, konsep, sifat-sifat, atau aturan matematika. (e) menuliskan simbol, notasi, dan bentuk representasi matematis, seperti tabel, diagram, grafik, dan lain-lain. Adapun tujuan penelitian ini adalah (1) mendeskripsikan persentase kemampuan pengetahuan matematis siswa dalam materi bentuk pangkat dan akar, (2) mendeskripsikan bentuk kesulitan yang dialami siswa dalam menyelesaikan soal pada materi bentuk pangkat dan akar, dan (3) mendeskripsikan faktor penyebab siswa kesulitan dalam menyelesaikan materi bentuk pangkat dan akar.

\section{METODE PENELITIAN}

Jenis penelitian yang digunakan dalam penelitian ini adalah kualitatif. Menurut Sugiyono (2015: 15), metode penelitian kualitatif adalah pendekatan penelitian yang berlandaskan pada filsafat postpositivisme, digunakan untuk meneliti pada kondisi obyek yang alamiah dimana peneliti adalah kunci, teknik pengumpulan data dilakukan secara dokumentasi dan trianggulasi (gabungan) analisis data bersifat kualitatif. Adapun sekolah yang menjadi tempat penelitian adalah SMA Negeri 4 Singkawang. Subjek dalam penelitian ini adalah siswa kelas X yang terdiri dari 30 siswa. 
Teknik analisis data yang digunakan dalam penelitian ini adalah penelitian deskriptif dengan pendekatan kualitatif. Moleong (2011:31) menyatakan penelitian deskriptif dirancang untuk mengumpulkan informasi dengan tujuan mendeskripsikan suatu gejala atau kejadian yang terjadi pada saat ini Dalam penelitian ini diperoleh data kulitatif sehingga untuk menganalisis data didapatkan dari pemberian tes tertulis dan wawancara.

\section{HASIL DAN PEMBAHASAN}

\section{Kemampuan Pengetahuan Matematis Siswa}

Berdasarkan hasil tes kemampuan pengetahuan matematis yang dikerjakan oleh siswa, diperoleh data persentase jumlah siswa dalam menjawab soal dan telah dikelompokan berdasarkan lima kategori kemampuan yang disajikan pada Gambar 1 .

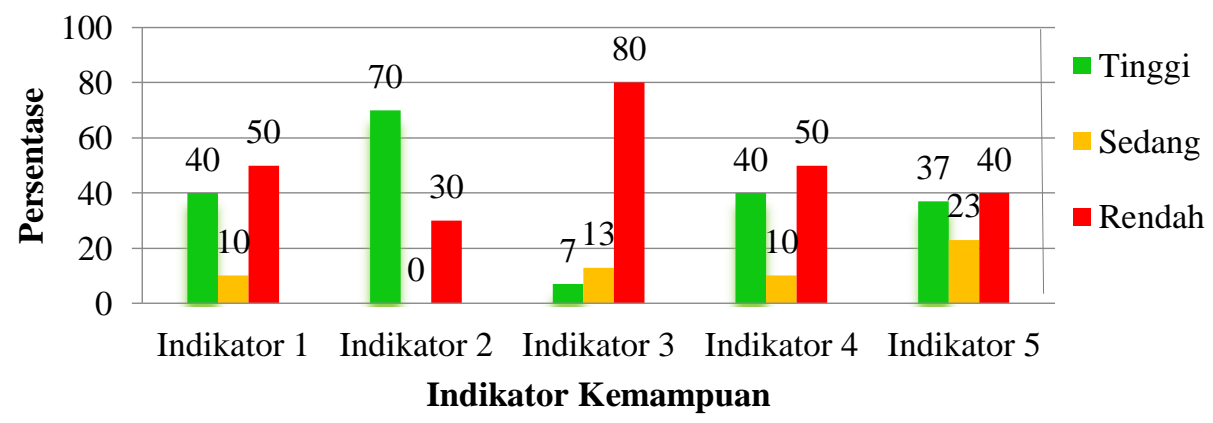

\section{Gambar 1. Diagram Persentase Siswa Per-Indikator Kemampuan Pengetahuan Matematis}

Berdasarkan Gambar 1, rata-rata persentase siswa dalam menjawab soal kemampuan pengetahuan matematis yang diperoleh dari 30 siswa, yaitu 39\% siswa memiliki tingkat pengetahuan yang tinggi, $11 \%$ siswa memiliki tingkat pengetahuan sedang, dan $50 \%$ siswa memiliki tingkat pengetahuan rendah. Hal ini sejalan dengan pendapat Sudjana (2007:116), kemampuan belajar siswa terutama memahami, menggali, dan informasi dari suatu materi pelajaran tentu tidak sama. Pada Gambar 1, dapat diketahui persentase jumlah siswa dalam menjawab soal per-indikator kemampuan diantara 30 siswa, pada indikator pertama $40 \%$ siswa berada pada kategori tinggi, $10 \%$ berada pada kategori sedang, dan 50\% siswa berada pada kategori rendah. Pada indikator kedua $70 \%$ siswa berada pada kategori tinggi dan 30\% siswa berada pada kategori rendah. Pada indikator ketiga $7 \%$ siswa berada pada kategori tinggi, $13 \%$ siswa berada pada kategori sedang dan $80 \%$ siswa berada pada kategori rendah. Pada indikator keempat $40 \%$ siswa berada pada kategori tinggi, $10 \%$ siswa berada pada kategori sedang dan 50\% siswa berada pada kategori rendah. Pada indikator kelima 37\% siswa berada pada kategori tinggi, $23 \%$ siswa berada pada kategori sedang dan $40 \%$ siswa berada pada kategori rendah.

\section{Bentuk Kesulitan Kemampuan Pengetahuan Matematis Siswa}

Bentuk kesulitan siswa dalam menyelesaikan soal pengetahuan matematis berdasarkan analisis terhadap jawaban siswa sebagai berikut:

a. Kesulitan fakta, yaitu kesulitan dalam mengenal dan menuliskan fakta bentuk pangkat dan akar yang disajikan pada Gambar 2.

$$
\frac{\text { d. } \frac{(-4)^{4}}{(-4)^{2}}-(-4)^{4-2} \neq(-4)^{2}}{\text { Gambar 2. Kesulitan Mengenal Fakta }}
$$

Pada kesulitan mengenal fakta bentuk pangkat, siswa rata-rata salah menunjukan seperti cuplikan jawaban siswa kode K-27 diatas. Dimana siswa melakukan kesulitan dalam menunjukan fakta 
dengan memilih simbol yang tidak sinkron. Padahal dalam masalah ini siswa hanya menunjukan simbol yang sinkron dengan hasil yang disajikan pada Gambar 3.

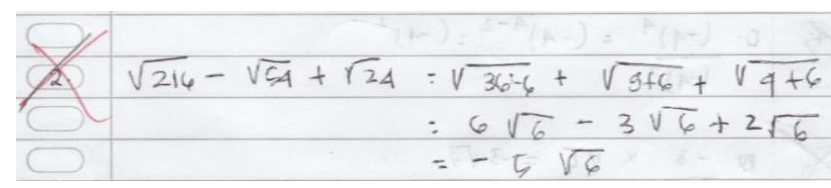

Gambar 3. Kesulitan Mengenal Fakta

Berdasarkan jawaban siswa tersebut, siswa mengalami kesulitan dalam proses menuliskan fakta atau simbol-simbol pada bilangan bentuk akar. Padahal dalam soal seperti ini seharusnya proses pengerjaannya menyederhanakan bentuk akar dengan simbol perkalian bukan pengurangan dan penjumlahan. terlihat $\sqrt{216}$ siswa menyederhanakan menjadi $\sqrt{36-6}$ seharusnya siswa menuliskan penyederhanan tersebut menjadi bentuk $\sqrt{36 \times 6}$.

b. Kesulitan konsep, yaitu kesulitan dalam mengenal dan menuliskan konsep bentuk pangkat dan akar yang disajikan pada Gambar 4.

\section{A. bllangan $R$ in $R$ arional}

Gambar 4. Kesulitan Mengenal Konsep

Berdasarkan cuplikan jawaban siswa tersebut, siswa salah menunjukan konsep yang tepat dalam menunjukan atau mengenal konsep. Siswa belum bisa mengenal konsep dengan baik ini terlihat bahwa konsep yang tepat dengan pernyataan bilangan yang tidak dapat dinyatakan dalam bentuk perbandingan $\frac{a}{b}$ dengan $a, b \in \mathrm{B}$ dan $\mathrm{b} \neq 0$ seharusnya bilangan irasioanal. Sedangkan untuk konsep bilangan rasioanal adalah bilangan yang dapat dinyatakan dalam bentuk perbandingan $\frac{a}{b}$ dengan $a, b \in \mathrm{B}$ dan $\mathrm{b} \neq 0$. Hal ini merupakan konsep yang tidak sama pengertianya, namun siswa belum bisa membedakan. Berikut kesulitan dalam menuliskan konsep yang disajikan pada Gambar 5.

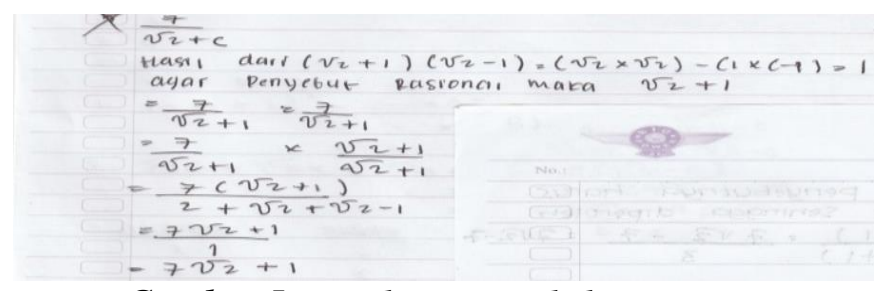

Gambar 5. Kesulitan Menuliskan Konsep

Berdasarkan jawaban siswa tersebut, siswa melakukan kesulitan dalam menuliskan konsep penyebut bilangan pecahan bentuk akar. Dalam proses merasionalkan penyebut tersebut siswa terlebih dahulu mencari bentuk sekawan hanya saja terlihat siswa salah menuliskan bentuk sekawanya $(\sqrt{2}+1)$ harus $(\sqrt{2}-1)$. Dan dalam proses menuliskan hasil menjadi salah total terlihat simbol-simbol yang seharusnya negatif menjadi positif. jawaban seharusnya Hasil dari $(\sqrt{2}+1)(\sqrt{2}-1)=(\sqrt{2} \times \sqrt{2})-(1 \times 1)=1$ Jadi agar penyebut dari $\frac{7}{\sqrt{2}+1}$ menjadi rasional, maka penyebutnya harus dikalikan dengan $(\sqrt{2}-1)$ Sehingga diperoleh $\frac{7}{\sqrt{2}+1}=\frac{7}{\sqrt{2}+1} \times \frac{(\sqrt{2}-1)}{(\sqrt{2}-1)}=$ $\frac{7 \sqrt{2}-7}{1}=7 \sqrt{2}-7$.

c. Kesulitan prinsip, yaitu kesulitan dalam mengenal dan menuliskan prinsip bentuk pangkat dan akar yang disajikan pada Gambar 6. 


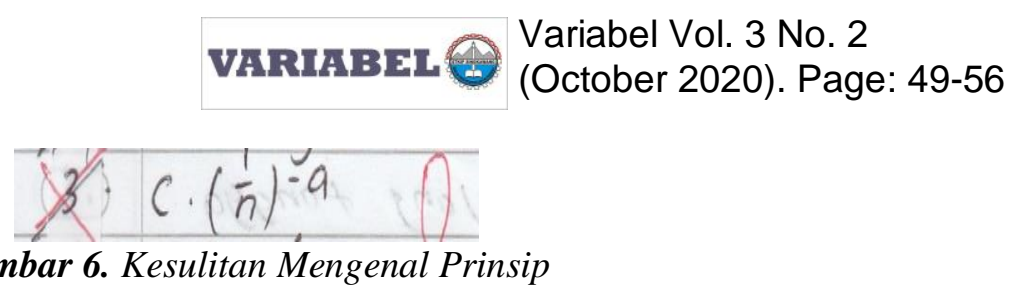

Berdasarkan jawaban tersebut, siswa melakukan kesulitan dalam menunjukan sifat atau prinsip dari bilangan perpangkatan. Seaharusnya dalam hal ini siswa bisa merubah $a^{-n}$ menjadi $\frac{1}{a^{n}}$, namun pengetahuan siswa masih belum cukup baik. Siswa salah dalam menunjukan sifat bentuk pangkat negatif siswa malah memilih $\left(\frac{1}{n}\right)^{-a}$. Berikut kesulitan dalam menuliskan sifat yang disajikan pada Gambar 7.

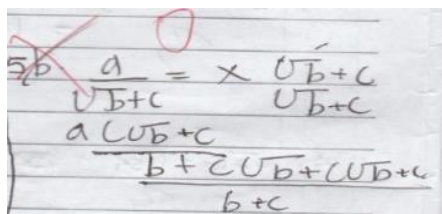

Gambar 7. Kesulitan Menuliskan Sifat

Berdasarkan cuplikan jawaban siswa tersebut, siswa kesulitan dalam menuliskan sifat dari pecahan bentuk akar. Terlihat dalam langkah penyederhanaan sifat pecahan bentuk akar siswa salah menuliskan penyebut. Padahal Untuk merasionalkan penyebut siswa harus mencari bentuk sekawan dari penyebut $\frac{a}{\sqrt{b}+c}$ dimana bentuk sekawannya adalah $\sqrt{b}-c$ sehingga jawaban seharusnya adalah untuk merasionalkan penyebut $\frac{a}{\sqrt{b}+c}$ perlu mengalikan $\frac{a}{\sqrt{b}+c}$ dengan $\frac{\sqrt{b}-c}{\sqrt{b}-c}$.

d. Kesulitan mendefinisikan, yaitu kesulitan dalam mendefinisikan konsep bentuk pangkat dan akar yang disajikan pada Gambar 8.

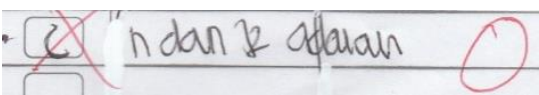

Gambar 8. Kesulitan Mendefinisikan Konsep Bentuk Pangkat

Berdasarkan cuplikan tersebut, siswa tidak bisa mendefinisikan konsep dari bentuk pangkat, dimana siswa tidak bisa melanjutkan jawabanya karena kurang dalam pengetahuan konsep bentuk pangkat. Padahal Siswa hanya perlu menjelaskan konsep kembali yang sudah ada di tabel dari soal cerita dimana siswa harusnya mengetahui banyak lipatan dan banyak bidang kertas yang dikatikan dengan bentuk eksponen siswa tidak bisa. Jawaban benarnya adalah $k$ merupakan hasil perpangkatan dan $n$ merupakan bilangan eksponen atau pangkat $k=2^{n}$. Berikut kesulitan dalam menuliskan sifat yang disajikan pada Gambar 9 .

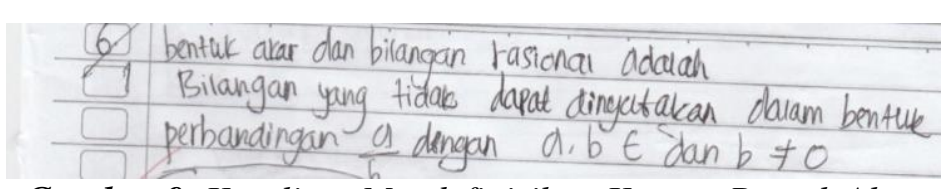

Gambar 9. Kesulitan Mendefinisikan Konsep Bentuk Akar

Kesulitan yang dialami siswa bisa dilihat dari cuplikan jawaban siswa tersebut. Pengetahuan siswa dalam mendefinisikan kembali bisa dikatakan rendah, banyaknya siswa yang tidak bisa membedakan bilangan rasional dan irasional terlihat pada cuplikan jawaban diatas yang mengatakan bilangan rasional merupakan bilangan yang tidak dapat dinyatakan dalam perbandingan $\frac{a}{b}$, dimana seharusnya siswa menuliskan bilangan rasional adalah bilangan yang dapat dinyatakan dalam perbandingan $\frac{a}{b}$. Hal ini terlihat jelas bahwa siswa melakukan kesulitan dalam mendefinisikan kembali konsep bentuk akar kedalam bentuk tulisan. Dimana jawaban benarnya adalah Bentuk akar adalah akar dari bilangan rasional yang hasilnya merupakan bilangan irasional. 
Bilangan rasional adalah bilangan yang dapat dinyatakan dalam bentuk perbandingan $\frac{a}{b}$, dengan $a$ merupakan bilangan bulat dan $b \neq 0$.

e. Kesulitan notasi, yaitu kesulitan dalam mengenal dan menuliskan notasi bentuk pangkat dan akar yang disajikan pada Gambar 10.

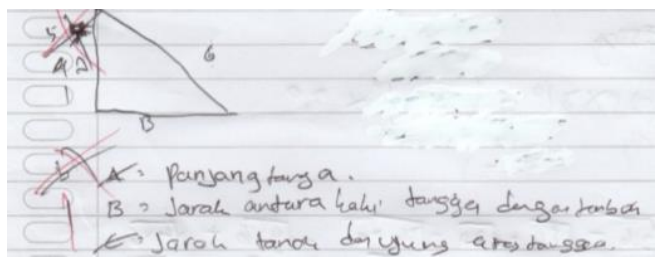

Gambar 10. Kesulitan dalam Mengenal dan Menuliskan Notasi

Berdasarkan cuplikan jawaban siswa tersebut menunjukan siswa masih kesulitan dalam menotasikan, bentuk notasi dari sebuah soal cerita atau bentuk representasi yang di gamabarkan dalam bentuk segitiga. Berdasarkan jawaban siswa tersebut siswa melakukan kesulitan dalam menuliskan notasi dimana seharusnya untuk menotasikan A pada sisi tegak itu adalah jarak tanah dengan ujung arah tangga, dan untuk yang $\mathrm{C}$ panjang tangga.

Hal ini sesuai dengan bentuk kesulitan yang dikemukakan oleh Ekawati (2018: 55) bahwa beberapa masalah atau kesulitan siswa dalam menyelesaikan soal matematika yaitu kesulitan memahami konsep, prinsip, simbol, alogaritma dan bahasa matematika.

\section{Faktor Penyebab Kesulitan Siswa dalam Menyelesaikan Soal Pengetahuan Matematis}

Faktor penyebab kesulitan siswa dalam menyelesaikan soal pengetahuan matematis berdasarkan analisis terhadap jawaban siswa sebagai berikut:

a. Kesulitan fakta, yaitu siswa kebingungan dan tidak memahami simbol matematika.

b. Kesulitan konsep, yaitu siswa tidak memaham konsep matematika.

c. Kesulitan prinsip, yaitu siswa lupa cara mengerjakan soal matematika yang diberikan, tidak adanya motivasi dan minat.

d. Kesulitan mendefinisikan, yaitu siswa tidak bisa mengingat kembali pengertian dari soal bentuk pangkat dan akar yang sudah pernah dipelajari.

e. Kesulitan notasi, yaitu tidak memahami soal yang diberikan dengan baik.

Hal ini sesuai dengan pendapat Jamal (2014:20) yang menegaskan bahwa kesulitan atau kendala yang dialami siswa dapat disebabkan oleh faktor internal adalah faktor yang berasal dari dalam diri siswa, misalnya bakat minat, motivas, intelegensi dan sebagainya.

\section{KESIMPULAN}

Kemampuan pengetahuan matematis kelas X SMA Negeri 4 Singkawang diperoleh diantara 30 siswa yaitu; 39\% siswa memiliki tingkat pengetahuan yang tinggi, $11 \%$ siswa memiliki tingkat pengetahuan sedang, dan 50\% siswa memiliki tingkat pengetahuan rendah. Bentuk kesulitan siswa dalam menyelesaikan soal pengetahuan matematis pada materi bentuk pangkat dan akar di kelas X Negeri 4 Singkawang yaitu fakta (kesulitan dalam mengenal dan menuliskan fakta), konsep (kesulitan dalam memahami dan menuliskan konsep), prinsip (kesulitan dalam memahami dan menuliskan prinsip), dan notasi (kesulitan dalam mengenal dan menuliskan notasi). Faktor penyebab kesulitan siswa dalam menyelesaikan soal pengetahuan matematis siswa pada materi bentuk pangkat dan akar di kelas $\mathrm{X}$ SMA Negeri 4 Singkawang berasal dari faktor internal yaitu siswa kebingungan atau lupa cara mengerjakannya, tidak adanya motivasi, minat dan tidak memahami soal dengan baik. 


\section{DAFTAR PUSTAKA}

Amelia, D. (2014). Analisis Hasil Belajar Matematika Siswa pada Pokok Bahasan Himpunan Berdasarkan Ranah Kognitif Taksonomi Bloom Kelas VII A di SMPN 14 Jember. Jurnal Edukasi UNEJ (Universitas Jember), 2(1), 1-4.

Azis. (2015). Analisis Kesulitan Kognitif dan Masalah Afektif Siswa SMA dalam Belajar Matematika Menghadapi Ujian Nasional Tahun Pelajaran 2013/2014 SMA di Kota Baubau. Jurnal JRPM (Jurnal Riset Pendidikan Matematika), 2(2), 162-174.

Ekawati. (2018). Kesulitan Belajar Matematika Berkaitan dengan Konsep pada Topik Aljabar: Studi Kasus pada Siswa Kelas VII Sekolah ABC Lampung. A Journal of Language, Literature, Culture, and Education, 14(1), 53-64.

Haji, S. (2015). Membangun Pengetahuan Matematika Siswa Sekolah Dasar melalui Pembelajaran Outdoor Mathematics. Prosiding Seminar Nasional Matematika dan Pendidikan Matematika UMS (Universitas Muhammadiyah Surakarta) 2015, 210-223.

Jamal, F. (2014). Analisis Kesulitan Belajar Siswa dalam Mata Pelajaran Matematika pada Materi Peluang Kelas XI IPA SMA Muhammadiyah Meulaboh Johan Pahlawan. Jurnal MAJU (Jurnal Pendidikan Matematika), 1(1), 18-36.

Moleong, L.J. (2011). Metodologi Penelitian Kualitatif. Bandung: Remaja Rosdakarya.

Permendikbud. (2016). Peraturan Menteri Pendidikan dan Kebudayaan Republik Indonesia Nomor 23 Tahun 2016 tentang Standar Penilaian Pendidikan. Jakarta: Kemendikbud.

Sudjana, N., \& Ahmad, R. (2007). Teknologi Pengajaran. Bandung: Sinar Baru Algesindo.

Sugiyono. (2015). Metode Penelitian Pendidikan. Bandung: Alfabeta.

Sulistyarini, D.A. (2016). Analisis Kesulitan Siswa SMK Citra Medika Sukoharjo dalam Menyelesaikan Soal Bentuk Akar dan Alternatif Pemecahannya. Prosiding Konferensi Nasional Penelitian Matematika dan Pembelajarannya (KNPMP I) Universitas Muhammadiyah Surakarta, 12 Maret 2016, 605-614.

Wahyuni, R. (2016). Pengaruh Model Role Playing terhadap Komunikasi Matematis Siswa pada Materi Fungsi Komposisi Kelas XI SMA Negeri 6 Singkawang. JPMI (Jurnal Pendidikan Matematika Indonesia), 1(2), 81-86.

Wahyuni, R., Mariyam., \& Sartika, D. (2018). Efektivitas Model Pembelajaran Creative Problem Solving (CPS) dalam Meningkatkan Kemampuan Berfikir Kritis Matematis Siswa pada Materi Persamaan Garis Lurus. JPMI (Jurnal Pendidikan Matematika Indonesia), 3(1), 26-31.

Zarkasyi, W. (2015). Penelitian Pendidikan Matematika. Karawang: Refika Aditama. 